\title{
Assessment of Arsenic (As), Lead (Pb) and Chromium (Cr) Accumulation in Different Organs of Commercially Important Fish Species Collected from Chattogram Coastal Region of Bangladesh.
}

\author{
Afifa Siddiqua ${ }^{\mathrm{a}, \mathrm{b}}$, Sk Istiaque Ahmed ${ }^{\mathrm{c}}$, Maria Al Mazed ${ }^{\mathrm{c}, \mathrm{d} \equiv}$, \\ Zannatun Nur Popy ${ }^{c}$, Md. Ashraful Islam ${ }^{a}$ and Md. Fahad Bin Quader ${ }^{a^{*}}$ \\ ${ }^{a}$ Department of Applied Chemistry and Chemical Technology, Chattogram Veterinary and Animal \\ Sciences University, Bangladesh. \\ ${ }^{b}$ District Food Safety Officer, Bangladesh Food Safety Authority, Ministry of Food, Bangladesh. \\ ${ }^{c}$ Department of Fisheries Resource Management, Chattogram Veterinary and Animal Sciences \\ ${ }^{d}$ Bangladesh Fisheries Research Institute (BFRI), Freshwater Station, Mymensingh, Bangladesh.
}

\section{Authors' contributions}

This work was carried out in collaboration among all authors. Authors MFBQ and SIA designed the experiment and author MFBQ provided all the logistic facilities. Author AS carried out the sample preparation and analysis with the guidance of authors MFBQ and SIA. Authors MAM and ZNP helped author AS in carrying out the experiment. Author AS wrote the manuscript with data interpretation. Authors SIA, MFBQ and MAI revised the manuscript critically for important intellectual content. All authors read and approved the final manuscript.

Article Information

DOI: $10.9734 / A R R B / 2022 / v 37 i 130480$

Open Peer Review History: This journal follows the Advanced Open Peer Review policy. Identity of the Reviewers, Editor(s) and additional Reviewers, peer review comments, different versions of the manuscript, comments of the editors, etc are available here: https://www.sdiarticle5.com/review-history/83589

Original Research Article

Received 15 November 2021 Accepted 20 January 2022

Published 22 January 2022

\section{ABSTRACT}

Aims: The purpose of this study was to evaluate whether there are any significant toxic effects of the widely exposed metals on different organs (gill, liver, kidney, and muscle) of some commercially important marine fish species (Herpodon nehereus, Pampus chinensis and Hilsa ilisha).

Study Design: The collection of the samples was done from January to March 2018 from Bay of Bengal near Chattogram city of Bangladesh. The study is based on randomly collected samples

\footnotetext{
इScientific Officer;

${ }^{*}$ Corresponding author: E-mail: fahadbinquader@cvasu.ac.bd;
} 
from the intended sampling sites (Randomized Block Design) to ensure the evenness and unbiases of the collected samples.

Methodology: Analyses were performed for metals such as arsenic (As), lead ( $\mathrm{Pb}$ ) and chromium (Cr) using Atomic Absorption Spectrophotometer (AAS). During each month, five individuals each with three replications from the three targeted species were collected, with a total of $135\left(45^{\star} 3\right)$ fishes in the study period.

Results: The concentrations of the metals found in the fishes varied in the following ranges: As: $0.029-0.071 \mathrm{ppm}, \mathrm{Pb}: 0.008-0.083 \mathrm{ppm}$ and $\mathrm{Cr}: 0.0001-0.03 \mathrm{ppm}$. The obtained result revealed the highest concentrations of all three metals were recorded in H.nehereus fish. The organ wise lead concentration was recorded highest in kidneys and gills of examined fishes with significant variation in muscles and liver. The scenario depicted quite differently in case of chromium where concentration in gills was found to be the highest with insignificant variation in accumulation in other three organs. In case of Arsenic, kidneys and livers were the most exposed two organs in comparison to significant exposure to muscles and gills. The obtained values of arsenic accumulation were considered critical for human consumption as it was higher than the recommended values stated by WHO and FAO; but the concentration of lead and chromium were found to be safe for human consumption. The values recorded for lead were increasingly approached to the safety values.

Conclusion: So, crucial steps should be taken regarding safety and environmentally friendly discharge of arsenic and lead; high levels of pollution will not only affect aquatic life but will also invite socio-economic disasters.

Keywords: Metals; Bay of Bengal; fish organs; bioaccumulation; atomic absorption spectroscopy; pollution.

\section{INTRODUCTION}

In Bangladesh, fish is a popular animal-source food in the diet of millions. It has been advised that fish should be consumed two or three times weekly, because of its high levels of essential amino acids (EAA), polyunsaturated fatty acid such as omega-3 and omega- 6 fatty acids [1,2]. The coastal water of Bangladesh comprises diverse fisheries resources with 475 finfish species [3]. The marine fisheries play significant role in the economy of Bangladesh. Total production of marine fisheries is 6.71 lakh MT and its contribution to total fish production is $14.90 \%$ with growth rate $1.70 \%$ [4]. In 20192020, fisheries and aquaculture sectors have become the second most important contributors in export earnings of Bangladesh, contributing to $3.52 \%$ in national GDP, $1.39 \%$ in export earnings and $26.37 \%$ in agriculture sector [4].

The metallic elements which have a higher density compared to water is termed as heavy metals [5]. Based on the hypothesis that heaviness and toxicity are closely related, heavy metals like Arsenic (As), Lead (Pb) and Chromium $(\mathrm{Cr})$ can be extremely toxic at a very low exposure [6]. The sources of heavy metal pollution are very diverse and covers a wide variety of ranges starting from geogenic sources to the atmospheric origin including domestic effluents, agricultural, industrial and pharmaceuticals sources [7] which eventually leads to a situation of prominent environmental pollution $[5,7,8]$.

As a result, in recent times, pollution caused by heavy metals in marine environment has attained a serious environmental concern. Due to the presence of heavy metals in aquatic environment, bioaccumulation occurs along the food chain. This eventually is carried into the organs of aquatic animals and may become toxic for fish and for people when it reaches a substantially high level. The organs of fish that take up heavy metals are the gills, skin, kidney, digestive tract, muscle, and liver [9]. Agriculture, shipping, urban, industrial wastes, and mining are the major sources of metal pollution in the aquatic environment [10]. Presence of arsenic, cadmium, chromium, mercury, nickel, and lead are indicative of anthropogenic influence in marine environment and are themselves of potential risk to the natural environment [11].

In many studies, fishes were the subject of investigation on metal accumulations and monitoring programs in seas or fresh water, due to their importance in human nutrition $[12,13,14]$. Such interest aimed at ensuring the safety to the food supply and minimizing the potential hazard effect on human health. The concentration of 
arsenic in muscle tissue of marine fish species collected from northeastern Bay of Bengal, India was studied $[15,16]$. They found considerable variation of arsenic levels among the fish species which were higher than the standard value of arsenic. As a commercial hub and the industrial nerve center of Bangladesh, Chattogram coastline of Bay of Bengal is at risk of having high levels of metal pollutants due to surrounding activities. According to studies [14,17], many kinds of industries are situated on Chattogram coast, each discharging its characteristic range of effluents containing metals and other harmful pollutants into the terrestrial and aquatic ecosystems. There are some studies on the pollution level of metals in water and sediments along the Karnafuli River and its adjacent coastal area $[18,19]$ but information on the types of metal in the Bay of Bengal coast including fish, other ecosystems, coastal areas, and rivers is poorly documented. With realizing the significance, the principal objectives of this research were: i) to determine the Arsenic (As), Lead (Pb) and Chromium (Cr) accumulation in different commercially important marine fishes collected from Chattogram coastal area. ii) to develop a comparison among different organs (Gill, Liver, Kidney and Muscle) and different species of investigated fishes in terms of those metal accumulation.

\section{MATERIALS AND METHODS}

\subsection{Study Design}

The study is designed based on randomly collected samples in the intended sampling sites (blocks). The target fish species were collected from the fishermen's nets of the Chattogram coast from where fishes are supplied to commercial fish markets in Chattogram, Bangladesh as well as to the other parts of the country. The samples were collected unbiasedly and the intention of this study to infer the effects of commonly exposed metals in the consumed fishes by human.

\subsection{Fish Collection}

Fishes were collected between January and March 2018 from the caught fishes by fishermen's nets from the Chattogram coast of Bay of Bengal. During each month, five individuals (each incorporating three replications, i.e., 15 fishes collected from the same time and station) from the three intended species $(H$. nehereus, $P$. chinensis and $H$. ilisha) were collected, with a total of $135\left(45^{\star} 3\right)$ fishes in the study period. Each time the fishes were transported to the Quality Control and Analytical Laboratory of Chattogram Veterinary and Animal Sciences University, Chattogram, Bangladesh. Fishes were stored in plastic bags at $-20^{\circ} \mathrm{C}$ until dissection.

\subsection{Fish Dissection and Preparation of Sample for Digestion}

The collected fishes were separated according to their species and separately dissected for their muscle, gill, liver and kidney tissues. For example, $45\left(3^{\star} 5^{\star} 3\right)$ muscle tissues for $H$. nehereus were collected during the three months of study period (Jan-Mar 2018). All the final sample preparation and chemical analysis for As, $\mathrm{Pb}$ and $\mathrm{Cr}$ were carried out according to the procedure described by UNEP Reference Methods [20]. The prepared samples were stored in $10 \%$ formalin solution for future analysis.

\subsection{Digestion}

The selected tissues were digested with concentrated nitric acid and perchloric acid (2:1 $\mathrm{v} / \mathrm{v})$ at $60{ }^{\circ} \mathrm{C}$ for 3 days and all samples were diluted with double distilled water by a microwave digester. Following acid digestion, all samples were analyzed for $\mathrm{As}, \mathrm{Pb}$ and $\mathrm{Cr}$ by atomic absorption spectrometry (Phillips AAS with double beam and deuterium background corrector).

\subsection{Arsenic (As), Lead (Pb) and Chromium (Cr) Analysis}

As, $\mathrm{Pb}$ and $\mathrm{Cr}$ were analyzed in a graphite furnace (GBCGF 3000 with Zeeman background corrector) with an auto sampler. All digested samples were analyzed three times for each metal. The standard addition method was used to correct for matrix effects (If any). The instrument was calibrated with standard solutions prepared from commercial materials. Analytical blanks were run in the same way as the samples and determined using standard solutions prepared in the same acid matrix.

\subsection{Data Analysis}

Statistical analysis was carried out using SPSS 20. One-way analysis of variance (ANOVA) and least significant difference (LSD) test were used to assess whether metal concentrations varied 
significantly among species \& organs. The average concentration of $\mathrm{As}, \mathrm{Pb}$ and $\mathrm{Cr}$ among each of the muscle, gill and kidney tissues collected from each species were used. The comparative accumulation of $\mathrm{Pb}, \mathrm{Cr}$ and $\mathrm{As}$ in each species was demonstrated by using Microsoft Excel. The level of significance of the mean values was assigned at $P<.05$.

\section{RESULTS AND DISCUSSION}

This study investigated $\mathrm{As}, \mathrm{Cr}$ and $\mathrm{Pb}$ distribution in different organs (gill, liver, muscle, and kidney) of three fish species (H.nehereus, $P$. chinensis and H.ilisha) captured from Chattogram coast of Bay of Bengal. These fish species were selected, as they are most consumed and commercially important marine fishes in Bangladesh. As, $\mathrm{Pb}$ and $\mathrm{Cr}$ were chosen because these are common detrimental elements found in industrial discharges.

The average of $\mathrm{As}, \mathrm{Pb}$ and $\mathrm{Cr}$ in different organs of the investigated species were presented in Fig. 1, Fig. 2 and Fig. 3. The comparisons of average metal contents of the organs and the species were shown in Table 1 and Table 2.

\subsection{Arsenic (As), Lead (Pb) and Chromium (Cr) Concentration in $H$. nehereus}

$H$. nehereus is economically important and they form a large part of the fish catch in the study area. The recorded values in $H$. nehereus expressed that the average value of arsenic obtained from muscle (0.039 ppm) was significantly $(P<.05)$ different from the values of gill (0.053 ppm), liver (0.064 ppm) and kidney $(0.071 \mathrm{ppm})$ which are higher than the recommended value of $0.01 \mathrm{ppm}$ for fish [21] (Fig. 1). This can be due to the high levels of arsenic disposure and from organo-arsenic compound stored in the marine environment [22].

The mean values of Chromium were the least among the three investigated metals $(0.03 \mathrm{ppm}$, $0.002 \mathrm{ppm}, 0.0005 \mathrm{ppm}$ and $0.00025 \mathrm{ppm}$ for gill, liver, kidney, and muscle respectively) which are far lower than the standard value (0.05-0.15 ppm) of Chromium stated by WHO and FEPA (Federal Environmental Protection Agency) $[23,24]$. There were however no significant difference in the chromium concentrations of different organs. The mean values of $\mathrm{Pb}$ for gills
(0.083 ppm), liver (0.029 ppm), kidney (0.083 $\mathrm{ppm})$ and muscle $(0.043 \mathrm{ppm})$ were observed (Fig. 1). All the values of lead were lower than the standard value (0.3 ppm) issued by European Commission [20]. From Fig. 1, the accumulation pattern of metals in different organs of $\mathrm{H}$. nehereus were: $\mathrm{As}>\mathrm{Pb}>\mathrm{Cr}$ for liver and $\mathrm{Pb}>\mathrm{As}>\mathrm{Cr}$ for kidney, gill and muscle. Concentrations of metals in muscle tissue of fish species collected from Northeast coast of India were determined [16]. They found higher concentration of Arsenic accumulation in Harpadon nehereus which was in agreement with this study.

\subsection{Arsenic (As), Lead (Pb) and Chromium (Cr) Concentration in $\boldsymbol{H}$. ilisha}

The recorded values in H.ilisha revealed that muscle had the lowest average arsenic 0.029 ppm while kidney had the highest average arsenic $0.070 \mathrm{ppm}$ which are higher than the recommended value of 0.01 ppm [21] (Fig. 2).

There was however no significant difference in arsenic contents of gill, liver and muscle except kidney. The observed values of Chromium in different organs were the least among the three investigated metals which are far lower than the standard value of Chromium [23,24]. The mean values of lead $(0.038 \mathrm{ppm}, 0.025 \mathrm{ppm}, 0.076$ ppm, $0.034 \mathrm{ppm}$ for gill, liver, kidney and muscle respectively) were observed which are also lower than the standard value of $0.3 \mathrm{ppm}$ and showed a significant $(P<.05)$ variation between lead contents of liver and kidney. The accumulation patterns in the gill and liver of the $H$. ilisha revealed the following order, $\mathrm{As}>\mathrm{Pb}>\mathrm{Cr}$. In the kidney and muscle, the concentrations revealed $\mathrm{Pb}>\mathrm{As}>\mathrm{Cr}$ sequence (Fig. 2).

\subsection{Arsenic (As), Lead (Pb) and Chromium (Cr) Concentration in Pampus chinensis}

The observed values in $P$. chinensis demonstrated that the mean values of arsenic obtained from kidney and gill $(0.067 \mathrm{ppm}$ and 0.029 ppm respectively) were significantly $(P<.05)$ different from the values of liver and muscle (0.036 ppm and $0.032 \mathrm{ppm}$ ) (Fig. 3) which are higher than the recommended value 0.01 ppm. [21] 


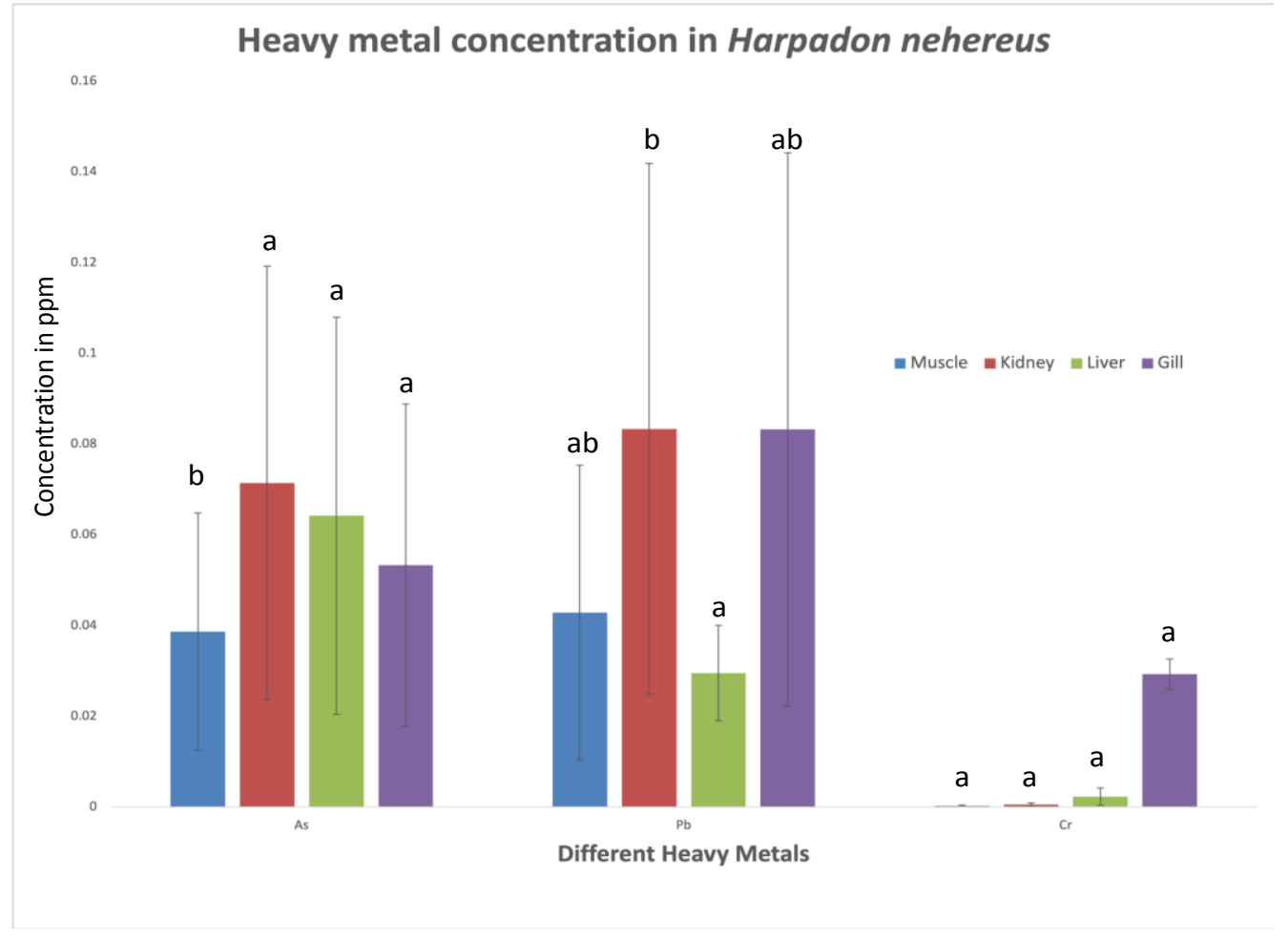

Fig. 1. Distribution of Arsenic (As), Lead (Pb) and Chromium (Cr) in different organs of $H$. nehereus. Bars with different letters $(a$ and $b)$ differ significantly $(P<0.05)$

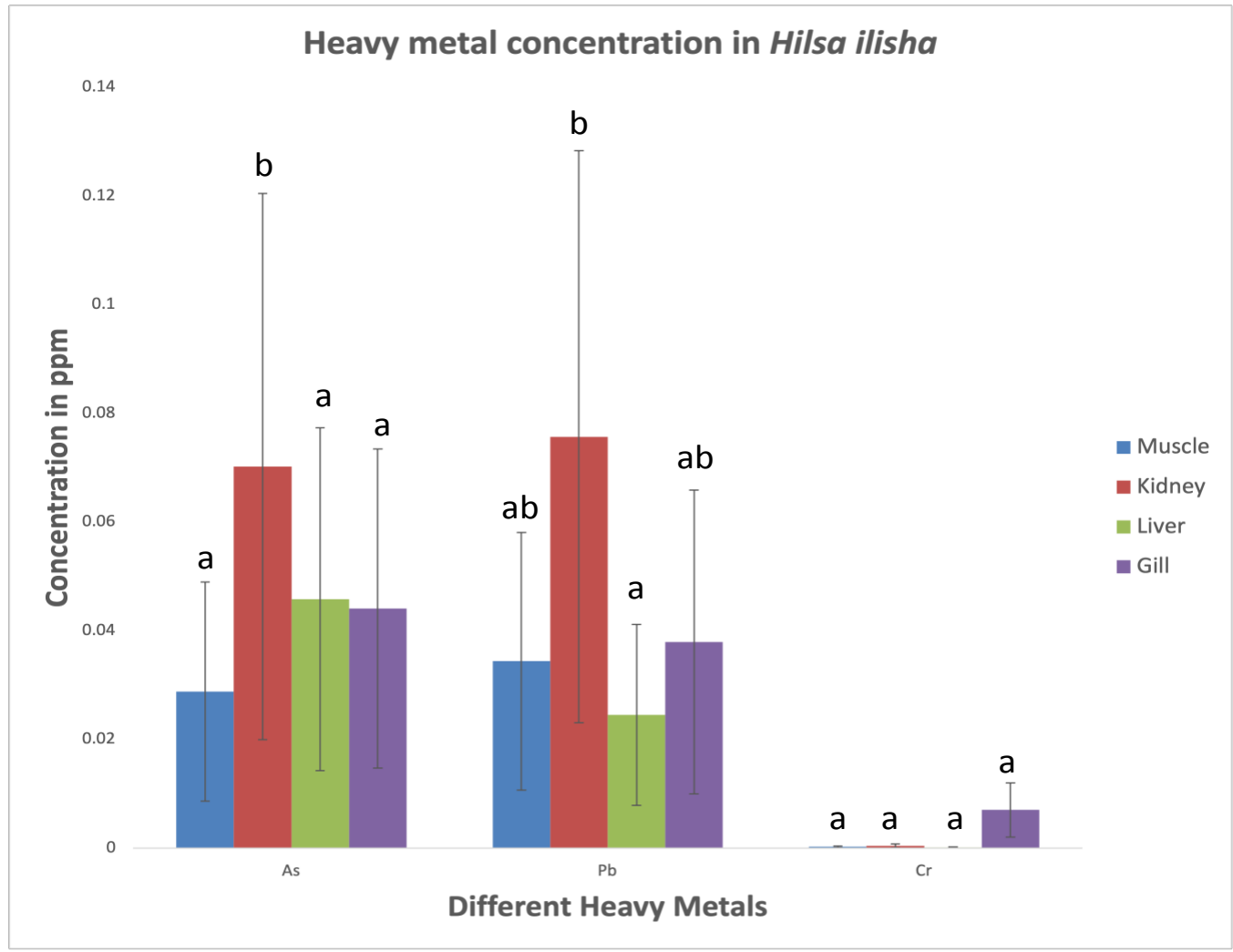

Fig. 2. Distribution of Arsenic (As), Lead (Pb) and Chromium (Cr) in different organs of $\boldsymbol{H}$. ilisha. Bars with different letters $(a$ and $b)$ differ significantly $(P<0.05)$ 


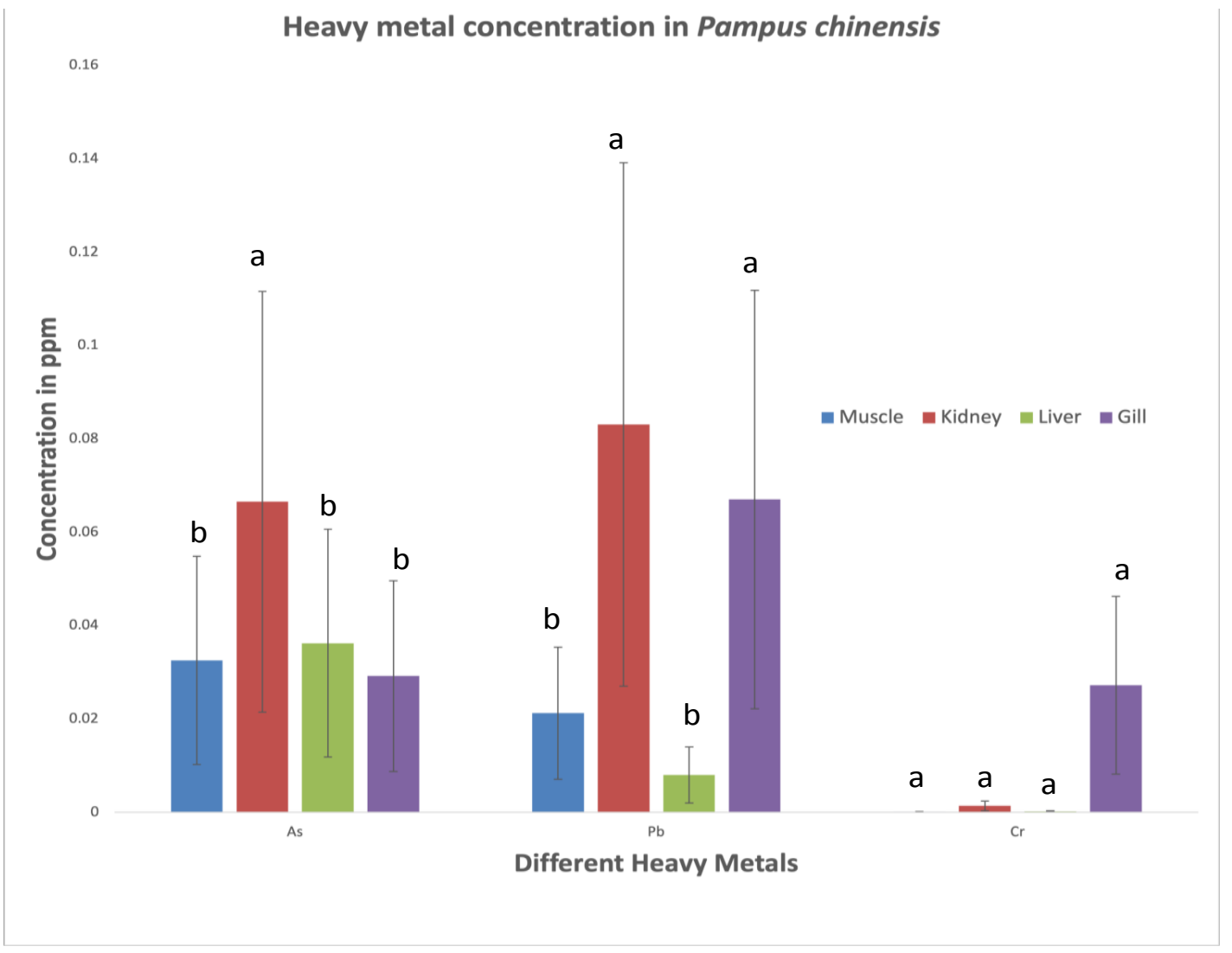

Fig. 3. Distribution of Arsenic (As), Lead (Pb) and Chromium (Cr) in different organs of $P$. chinensis. Bars with different letters $(a$ and $b)$ differ significantly $(P<0.05)$

Table 1. The comparison of different organs of the species with respect to the Arsenic (As), Lead $(\mathrm{Pb})$ and Chromium $(\mathrm{Cr})$ accumulation levels

\begin{tabular}{llll}
\hline Heavy metal & H. nehereus & P. chinensis & H. ilisha \\
\hline Ar & $\mathrm{K}^{1}>\mathrm{L}^{1}>\mathrm{G}^{2}>\mathrm{M}^{2}$ & $\mathrm{~K}^{1}>\mathrm{L}^{1}>\mathrm{M}^{2}>\mathrm{G}^{2}$ & $\mathrm{~K}^{1}>\mathrm{L}^{1}>\mathrm{G}^{2}>\mathrm{M}^{2}$ \\
$\mathrm{~Pb}$ & $\mathrm{~K}^{1}=\mathrm{G}^{1-2}>\mathrm{M}^{1-2}>\mathrm{L}^{2}$ & $\mathrm{~K}^{1}>\mathrm{G}^{1-2}>\mathrm{M}^{1-2}>\mathrm{L}^{2}$ & $\mathrm{~K}^{1}>\mathrm{G}^{1}>\mathrm{M}^{2}>\mathrm{L}^{2}$ \\
$\mathrm{Cr}$ & $\mathrm{G}^{1}>\mathrm{L}^{1}>\mathrm{K}^{1}>\mathrm{M}^{1}$ & $\mathrm{G}^{1}>\mathrm{K}^{1}>\mathrm{L}^{1}=\mathrm{M}^{1}$ & $\mathrm{G}^{1}>\mathrm{K}^{1}>\mathrm{M}^{1}=\mathrm{L}^{1}$ \\
\hline
\end{tabular}

${ }^{*}$ The difference in the metal accumulation levels of the organs with a different number in the same row relating to any species is significant $(P<.05)$.

$K=$ kidney; $G=$ gill; $L=$ liver; $M=$ muscle.

The mean values of Chromium in different organs were the least among the three investigated metals which are far lower than the standard value [23-25]. There was no significant difference in the chromium concentrations of different organs. The average values of lead were also observed (0.067 ppm, $0.008 \mathrm{ppm}, 0.083 \mathrm{ppm}$ and 0.021 ppm for gill, liver, kidney and muscle respectively) which are also lower than the standard value. The accumulation levels of metals in organs of $P$. chinensis were: $\mathrm{Pb}>\mathrm{As}>\mathrm{Cr}$ for gill and kidney and $\mathrm{As}>\mathrm{Pb}>\mathrm{Cr}$ for liver and muscle (Fig. 3).
In this study, arsenic and lead had the highest concentrations in all tissues of the investigated species while chromium was the element that had the lowest detected concentration.

\subsection{Organ and Species Wise Arsenic (As), Lead (Pb) and Chromium (Cr) Concentration}

The data in Table 1 portrays significant differences in the metal amounts except $\mathrm{Cr}$ among different organs and among different investigated species. It has been reported that the liver, the gill, and the kidney could accumulate heavy metals in higher concentration 
compared to the muscle $[26,27]$ which on the other hand can be a blessing as muscle is the most consumed part widely.

When we consider the organs of all three fishes, highest concentration of arsenic was estimated in kidney and second-best value was recorded in liver (Table 1). Arsenic concentrations in liver and kidney found statistically different from gill and muscle. This might be related to the feeding habit of fish species which feeds on decayed organic matter and the planktonic sources. Fishes can develop pollutant-sequestering detoxifying systems, because of which fishes are not significantly affected by the toxicity of heavy metal pollutants [28], but the secondary consumers like human can be affected by this.

In case of all three fishes, highest lead concentration was estimated in kidney and the second-best value was recorded in gill. The recorded values in liver and muscle were significantly different from the kidney and gill (Table 1). However, a study in the west coast of India found that lead concentration exceeded maximum permissible limits in gill (1.55 ppm) and liver $(0.85 \mathrm{ppm})$ tissues of Harpodon nehereus during monsoon period [29]. On the contrary, another study reported higher concentration of lead in the liver than the gill and the kidney [30]. The possible reasoning of these can be because of the variability of the environment as well as the nature of the species investigated.

For all three marine fishes, chromium concentration was found highest in gill with very lower value in liver, kidneys and muscles which were not statistically different (Table 1). An
MSDS (Material Safety Data Sheet) report showed that chromium accumulates primarily in the gill, liver, kidney, and bone in different fish species [31] because these internal organs directly encounter the water through respiration. The observation of this study agrees with those of another study [32]. For instance, the muscle $\mathrm{Pb}$ contents of three investigated fish species were remarkably higher than a metabolite organ, liver (Table 1). This finding could be due to the specific bioaccumulation characteristics of fishes which is especially specific to different species and the elements $[33,34]$.

So, as of Table 1 which shows that in terms of organ the metals were mostly concentrated in the kidney tissues. But the concentration in muscle was found to be the lowest which is a positive finding as we consume the muscles widely even though the concentration of arsenic in muscles was recorded higher than the safety values. The higher concentration in arsenic in edible parts like muscles can be because of the higher level of bioaccumulation of this heavy metal compared to the other investigated metals. Therefore, there is a clear need of further studies which can reveal the nature of Arsenic accumulation in the different organs of fishes and its variability compared to other metallic elements.

It was observed that $H$. nehereus showed the highest metal accumulation value compared to the other two species (Table 2). As $H$. nehereus occupies a higher trophic level of the food chain, the bioaccumulation process may increase the concentration of metals in their bodies.

Table 2. The comparison of the fish species with respect to the Arsenic (As), Lead $(\mathrm{Pb})$ and Chromium (Cr) accumulation levels of the organs

\begin{tabular}{|c|c|c|}
\hline Heavy metal & Organ & Fish species \\
\hline \multirow{4}{*}{$\mathrm{Ar}$} & Gill & H. nehereus $^{1}>H$. ilisha ${ }^{1-2}>P$. chinensis ${ }^{2}$ \\
\hline & Liver & H. nehereus ${ }^{7}>H$. ilisha ${ }^{1-2}>P$. chinensis ${ }^{2}$ \\
\hline & Kidney & H. nehereus ${ }^{\top}>H$. ilisha ${ }^{7}>P$. chinensis ${ }^{7}$ \\
\hline & Muscle & H. nehereus ${ }^{1-2}>P$. chinensis ${ }^{1}>H$. ilisha \\
\hline \multirow[t]{4}{*}{$\mathbf{P b}$} & Gill & H. nehereus ${ }^{1-2}>P$. chinensis $^{1}>H$. ilisha ${ }^{2}$ \\
\hline & Liver & H. nehereus ${ }^{7}>H$. ilisha ${ }^{7}>P$. chinensis $^{7}$ \\
\hline & Kidney & H. nehereus ${ }^{7}>P$. chinensis ${ }^{7}>H$. ilisha ${ }^{7}$ \\
\hline & Muscle & H. nehereus ${ }^{7}>H$. ilisha $^{7}>P$. chinensis $^{7}$ \\
\hline \multirow[t]{4}{*}{$\mathrm{Cr}$} & Gill & H. nehereus ${ }^{7}>P$. chinensis $>$ $>$. ilisha ${ }^{7}$ \\
\hline & Liver & H. nehereus ${ }^{7}>P$. chinensis $^{7}=H$. ilisha ${ }^{7}$ \\
\hline & Kidney & H. nehereus ${ }^{7}>P$. chinensis $^{7}=H$. ilisha ${ }^{7}$ \\
\hline & Muscle & H. nehereus ${ }^{7}>P$. chinensis $^{7}=H$. ilisha $^{7}$ \\
\hline
\end{tabular}

${ }^{\star}$ The difference in the metal accumulation levels of the marine fish species with a different number in the same row is significant $(P<.05)$. 
The bio- accumulation mechanism involves uptake of the metal with food taken by marine organisms. The food is digested, assimilated, and excreted but the metal accumulates in the organs of the fishes [35]. The metal concentrations of different marine fish species have been widely studied $[36,13,37,38,29]$.

Despite the limitation of time frame, budgeting, and logistic facilities; the findings of this study create the passage to think critically for ensuring a sustainable pollutant free environment for marine fishes and draw special emphasize on the Chattogram coast of Bangladesh. There are similarities, as well as differences, between the results from our study and the findings from another research. It has been indicated that the levels of metals in fish depend on habitats, the durations of exposure of the fish to contaminants, their feeding habits and the age and the size of the species $[39,40]$.

Therefore, we can conclude that the studied value of arsenic is higher than the recommended values of human intake in all the three cases of fish, indicating the low water quality of Chattogram coastal area. The Chattogram coastal water might be highly polluted with arsenic. It could be associated to effluent discharges from a major industrial and siderurgic plant near the sea and to agro-industrial activities, mainly run off from agricultural soils where fertilizers are used and other waste [14].

\section{CONCLUSION}

As being a widely exposed coast of the Bay of Bengal, Chattogram coast is affected by numerous numbers of metals. As this region is the principal harvesting areas of marine fishes, this metal toxicity can cause indeed a supreme problem in human health. From the findings of this study, it was concluded that the fish kidney exhibited highest accumulation of metals (As and $\mathrm{Pb})$ in H.nehereus ,P. chinensis and H.ilisha. Fish gill showed highest accumulation of $\mathrm{Cr}$ in three investigated fish species which is lower than the standard value of $\mathrm{Cr}$. The current research has revealed that arsenic concentration is far above from the safety levels while the concentration of lead is also approaching the acceptable limit. The immediate safety and strict regulatory actions on environment friendly discharge metal is mandatory which should be ensured by the government organizations as well as by the non-government responsible personnel and organizations.

\section{ACKNOWLEDGEMENTS}

Authors gratefully acknowledge the University Grants Commission of Bangladesh providing fund for this research work. Authors are also thankful to Quality Control and Analytical Laboratory of Chittagong Veterinary and Animal Sciences University, Chattogram, Bangladesh for providing laboratory supports to carry out this study successfully.

\section{COMPETING INTERESTS}

Authors have declared that no competing interests exist.

\section{REFERENCES}

1. Gjedrem T, Robinson N, Rye M. The importance of selective breeding in aquaculture to meet future demands for animal protein: A review. Aquac. 2012;350353(3):117-129.

DOI:10.1016/j.aquaculture.2012.04.008.

2. Kris-Etherton PM, Harris WS, Appel LJ. Fish consumption, fish oil, omega-3 fatty acids, and cardiovascular disease. Circ. 2002;106(21):2747-2757.

Available:https://doi.org/10.1161/01.CIR.00 00038493.65177.94.

3. Mazid MA. Manual on culture of small and threatened indigenous fish species. Bangladesh Fisheries Research Institute, Department of Fisheries, Bangladesh Agricultural University and Ministry of Fisheries and Livestock; 2005. Accessed 25 June 2021.

4. DoF. Department of Fisheries, Yearbook of fisheries statistics of Bangladesh, 2019-20.

Fisheries Resources Survey System (FRSS), Department of Fisheries. Bangladesh: Ministry of Fisheries and Livestock. 2020;37:141.

Available:http://www.fisheries.gov.bd.

5. Fergusson JE, editor. The heavy elements: chemistry, environmental impact and health effects. Oxford: Pergamon Press; 1990.

6. Duffus $\mathrm{JH}$. Heavy metals-a meaningless term? Pure Appl Chem. 2002;74(5):793807.

DOI: 10.1351/pac200274050793

7. He ZL, Yang XE, Stoffella PJ. Trace elements in agroecosystems and impacts on the environment. $\mathrm{J}$ Trace Elem Med Biol. 2005;19(2-3):125-140.

DOI:10.1016/j.jtemb.2005.02.010 
8. Goyer RA. Toxic effects of metals. In: Klaassen CD, editor. Cassarett and Doull's Toxicology: The Basic Science of Poisons. New York: McGraw-Hill Publisher; 2001;811-867.

9. Annabi A, Said K, Messaoudi I. Cadmium: bioaccumulation, histopathology and detoxifying mechanisms in fish. Am $\mathrm{J}$ Res Comun. 2013;1(4):60-79.

10. Gumgum B, Gulsun Z, Unlu E. Heavy metal pollution in water, sediment and fish from the Tigris River in Turkey. Chemosphere. 1994;29(1):111-116.

DOI:10.1016/0045-6535(4)90094-9

11. Idris AM, Alqahtani F, Said TO, Fawy KF. Contamination level and risk assessment of heavy metal deposited in street dusts in Khamees-Mushait city, Saudi Arabia. Hum Ecol Risk Assess: An International Journal. 2018;26(2):495-511.

DOI:10.1080/10807039.2018.1520596

12. Sioen I, Henauw SD, Verdonck FAM, Thuyne NV, Camp VJ. Development of a nutrient database and distributions for use in a probabilistic risk-benefit analysis of human seafood consumption. J Food Compos Anal. 2007;20(8):662-670. DOI:10.1016/j.jfca.2006.11.001.

13. Sujatha K, Durairajsinghu V, Silambarasan $\mathrm{K}$. Determination of some heavy metals in fish, water and sediments from bay of bengal. Pollut res. 2016;35(4):797-799.

Available:https://www.researchgate.net/pu blication/317202279

14. Jothi JS, Anka IJ, Hashem S, Morshed S. Assessment of heavy metal concentration in edible fish muscle and water sample collected from different location in Chittagong: a public health concern. Ukr Food J. 2018;7(3).

DOI:10.24263/2304-974X-2018-7-3-11

15. Mukherjee DP, Kumar B. Assessment of arsenic, cadmium and mercury level in commonly consumed coastal fishes from Bay of Bengal, India. Food Sci Qual Manag. 2011;2. ISSN 2224-6088 (Paper) ISSN 2225-0557 (Online).

Available:www.iiste.org;

16. Kumar B, Sajwan KS, Mukherjee DP. Distribution of Heavy Metals in Valuable Coastal Fishes from North East Coast of India. Turkish J Fish Aquat Sci. 2012;12:81-88.

DOI:10.4194/1303-2712-v12_1_10

17. Monwar M. Flow and discharge characteristics in the Karnaphuli River Estuary. In-term Research Paper. Institute of Marine Sciences, Chittagong University, Bangladesh; 2001.

18. Khan MU, Muhammad S, Manik RN, Khan AK, Tariq M. Heavy metals potential health risk assessment through consumption of wastewater irrigated wild plants: A case study. Hum Ecol Risk Assess. 2015;22(1). DOI:10.1080/10807039.2015.1056292

19. Rashid H, Hasan MN, Tanu MB, Parveen R, Sukhan ZP, Rahman MS, Mahmud Y. Heavy metal pollution and chemical profile of Khiru River, Bangladesh. Int J Environ. 2015;2(1):57-63. Accessed 24 March 2012.

Available:http://www.BENJapan.org/lJE.

20. UNEP. Sampling of selected marine organisms and sample preparation for trace metal analysis: Reference Method for Marine Pollution Studies. 1984;7(2):19.

21. WHO (World Health Organization). Guidelines for drinking-water quality, 3rd. Geneva: World Health Organization, WHO Food Standards Programme, Codex Committee, Rotterdam. Reference CX/FAC 02/16; 2004.

22. Neff JM. Ecotoxicology of arsenic in the marine environment. Environ. Toxicol. Chem. 1997;16(5):917-927.

DOI: $10.1002 /$ etc.5620160511

23. WHO (World Health Organization). Recommendation WHO; Geneva: Guidelines for Drinking Water Quality. 1985;1:130.

24. FEPA. Federal Environmental Protection Agency. Guidelines and Standards for Environmental Pollution Control in Nigeria. 2003;238.

25. European Commission, Commission Regulation (EC) No. 629/2008, Amending Regulation (EC) No. 1881/2006 setting maximum levels for certain contaminants in foodstuffs. Official Journal of the European Union. 2008;L173:6-9.

26. Bashir F, Alhemmali E. Analysis of some heavy metal in marine fish in muscle, liver and gill tissue in two marine fish spices from Kapar coastal waters, Malaysia. The Second Symposium on Theories and Applications of Basic and Biosciences. 2015;2.

Available:http://www.researchgate.net/publ ication/301554192.

27. Vijayasundaram V, Nagar A. The bioaccumulation of arsenic and the efficacy of Meso2, 3-dimercaptosuccinic Acid in the Selected Organ Tissues of Labeorohita Fingerlings Using Inductively Coupled 
Plasma-Optical Emission Spectrometry. World Appl Sci J. 2009;6(9):1247-1254.

Available:http://www.researchgate.net/publ ication/254606465

28. Weis JS, Weis P. Effects of environmental pollutants on early fish development. Reviews in Aquatic Sciences. 1989;1:4573.

29. Oza A, Muralidharan L. Seasonal study on bioaccumulation of heavy metal, lead in various tissues of fish, harpodonnehereus collected from sassoon dock, mumbai coast of maharshtra, India. Int J Adv Res Sci Eng. 2018;7(4):265-272.

Available:https://www.researchgate.net/pu blication/333688552.

30. Farombi EO, Adelowo OA, Ajimoko YR. Biomarkers of oxidative stress and heavy metal levels as indicators of environmental pollution in African Cat Fish (Clariasgariepinus) from Nigeria Ogun River. Int $\mathrm{J}$ Environ Res Public Health. 2007;4(2):158-65.

DOI:10.3390/ijerph2007040011.

31. MSDS. The MSDS hyperglossary heavy metal; 2006

Available:http://www.ilpi.com/msds/ref/hea vy metal.html.

32. Amundsen PA, Staldvik FJ, Lukin AA, Kashulin NA, Popova OA, Reshetnikov YS. Heavy metal contamination in freshwater fish from the border region between Norway and Russia. Sci Total Environ. 1997;201(3):211-224.

DOI: 10.1016/s0048-9697(97)84058-2

33. Henry F, Amara R, Courcot L, Lacouture $D$, Bertho ML. Heavy metals in four fish species from the French coast of the Eastern English Channel and Southern Bight of the North Sea. Environ Int. 2009;30(5):675-83.
DOI: 10.1016/j.envint.2003.12.007

34. Papagiannis I, Kagalou I, Leonardos J, Petridis D, Kalfakakou V. Copper and zinc in four freshwater fish species from Lake Pamvotis (Greece). Environ Int. 2004;30(3):357-362.

Available:https://doi.org/10.1016/j.envint.20 03.08.002.

35. Goel PK. Water pollution: causes, effects and control, New Age International (P) Limited, New Delhi, India. 1996;97-115.

36. Chakraborty S, Rudra T, Guha A, Ray A, Pal N, Mitra A. Spatial variation of heavy metals in Tenualosailisha muscle: A case study from the lower Gangetic delta and coastal West Bengal. Int J Inno Sci, Eng Tech. 2016;3:4.

37. Younis A, Amin H, Alkaladi A, Mosleh Y. Bioaccumulation of heavy metals in fish, squids and crustaceans from the Red Sea, Jeddah Coast, Saudi Arabia. Open Mar Sci. 2015;5(4):369-378.

DOI:10.4236/ojms.2015.54030.

38. Salam MA, Paul SC, Noor SNBM, Siddiqua SA, Aka TD, Wahab $R$ and Aweng ER. Contamination profile of heavy metals in marine fish and shellfish. Glob $\mathrm{J}$ Environ Sci. 2019;5(2):225-236. DOI:10.22034/gjesm.2019.02.08.

39. Canli M, Atli G. The relationships between heavy metal ( $\mathrm{Cd}, \mathrm{Cr}, \mathrm{Cu}, \mathrm{Fe}, \mathrm{Pb}, \mathrm{Zn}$ ) levels and the size of six Mediterranean fish species. Environ Pollut. 2003;121(1):129136.

Available:https://doi.org/10.1016/S02697491(02)00194-X.

40. Rashed MN. Monitoring of environmental heavy metals in fish from Nasser Lake. Environ Int. 2001;27(1):27-33.

DOI: 10.1016/s0160-4120(01)00050-2.

(c) 2022 Quader et al.; This is an Open Access article distributed under the terms of the Creative Commons Attribution License (http://creativecommons.org/licenses/by/4.0), which permits unrestricted use, distribution, and reproduction in any medium, provided the original work is properly cited.

Peer-review history:

The peer review history for this paper can be accessed here: https://www.sdiarticle5.com/review-history/83589 